\title{
U.S. Farm Policy: An Australian Perspective
}

\author{
Geoff Edwards
}

$\mathbf{P}$ programs are inefficient, costly and unfair." The Australian prime minister, Мr. Hawke, agrees with that assessment, and considers it applicable to the European Economic Community and Japan also.

This paper compares the role and the recent situation of agriculture in the United States and Australia, assesses the intemational impact of U.S. farm policy and discusses possible approaches to reducing protection for agriculture in the Unted States and elsewhere in the world.

\section{UNITED STATES AND AUSTRALIAN FARMING: A BRIEF COMPARISON}

The relative importance of farming in the United States and Australian economies from 1957 to 1987 is shown in table 1. Farming's contribution to GNP fell from 4 percent to less than 2 percent in the United States; the fall in Australia was from over 14 percent to less than 4 percent. While the share of faming in employment was 50 percent higher in each country than the recent farm GNP component, it also fell substantially, especially in the United States over the three decades shown.

Geoff Eowards is a senior lecturer in agricultural economics at LaTrobe University, Melbourne, Australia. This paper was presented at the annual meeting of the Federal Reserve System Committee on Agriculture and Rural Development held at the Federal Reserve Bank of St. Louis on May 21, 1987.

See Council of Economic Advisers (1987).

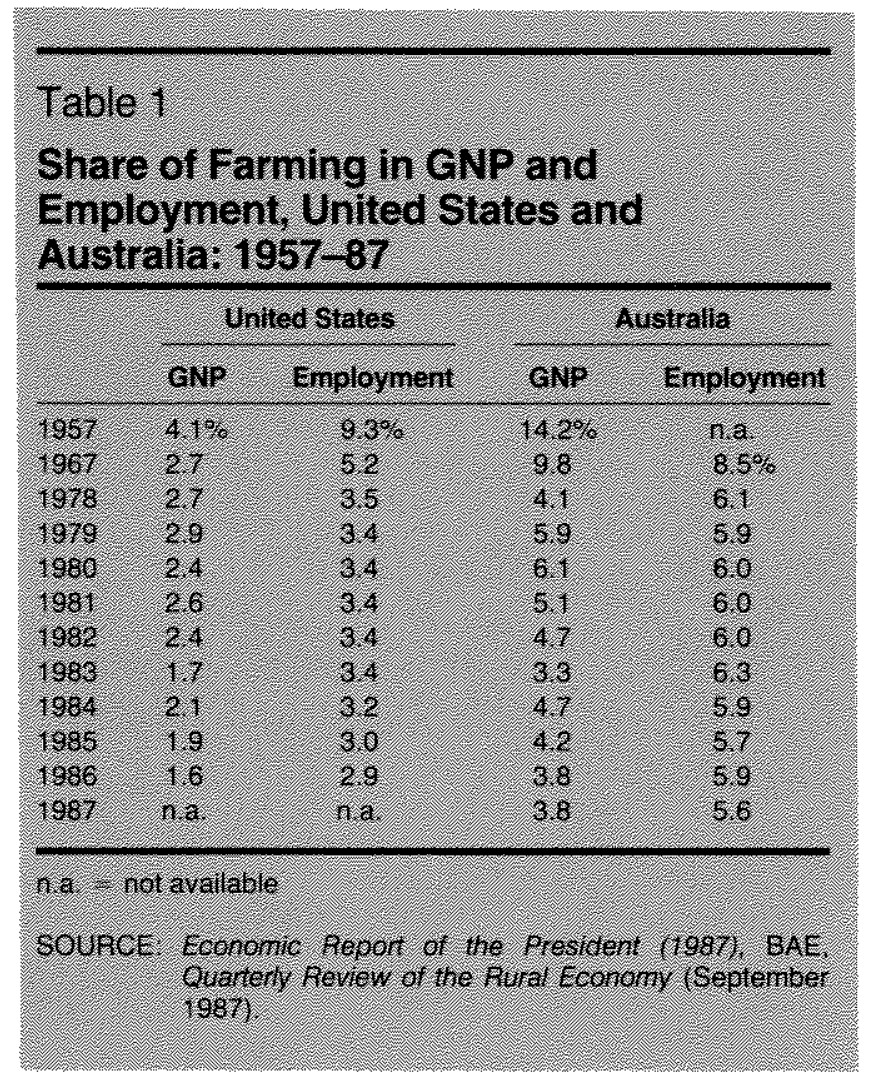

The percentage contributions of farm exports to total merchandise exports in the two countries are shown in table 2. This contribution was generally more than twice as high in Australia as in the United States. The proportionate fall in agriculture's share of exports over the decade to 1986 was higher in the United States than in Australia. 


\section{Table 2}

\section{Share of Farm Exports in Total Merchandise Exports, United States and Australia: $1976-87$}

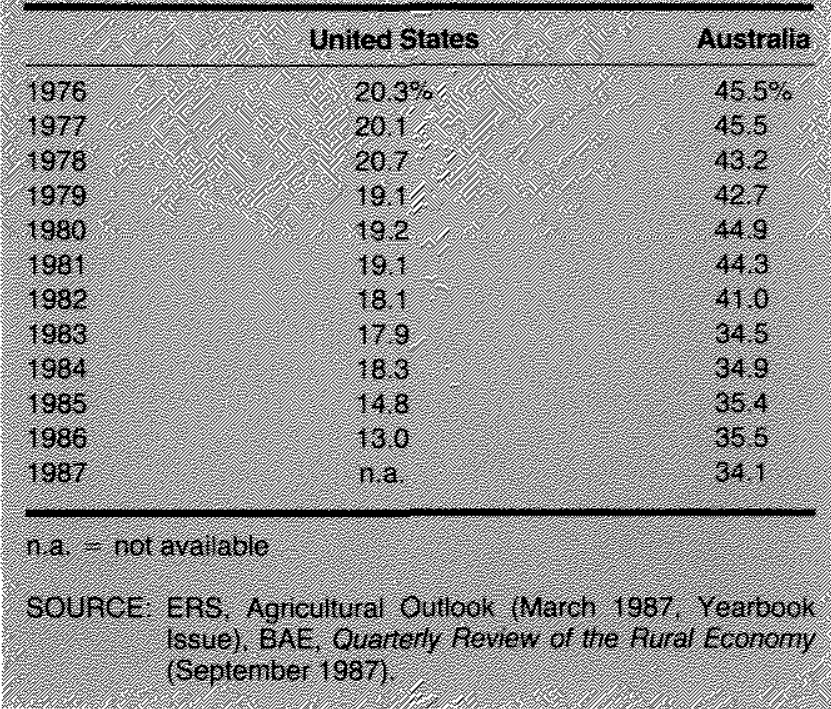

Putting the shares of farm exports in total (merch disel exports together with the shares of exports GNP 4.8 percent in the United States in 1986 and 1 percent in Australia indicates that the Austral economy is affected to a much greater relative ext than is the U.S. by developments in world markets farm commodities.

For most of the 1980s, farm income in the Uni States and Australia has been depressed. This shc up most clearly by comparing deflated (or real fa income in the 1980 s and the 1970 s (see table 3 ). Onl: 1987 is United States real farm income expected reach the levels it attained the second half of the 19 after being well below them until 1985. In Austar there is more ground to make up. Real farm incomt 1987 was less than half its level in the second hal the 1970 s, with a rise to 60 percent being expectec 1988.

The proportionate increase in farm indebtedn has been much greater in Australia than in the Uni States (table 4). From 1976 to 1987 , farm indebtedn in Australia rose faster than the 9 percent a $y$ increase in the consumer price index, while fa

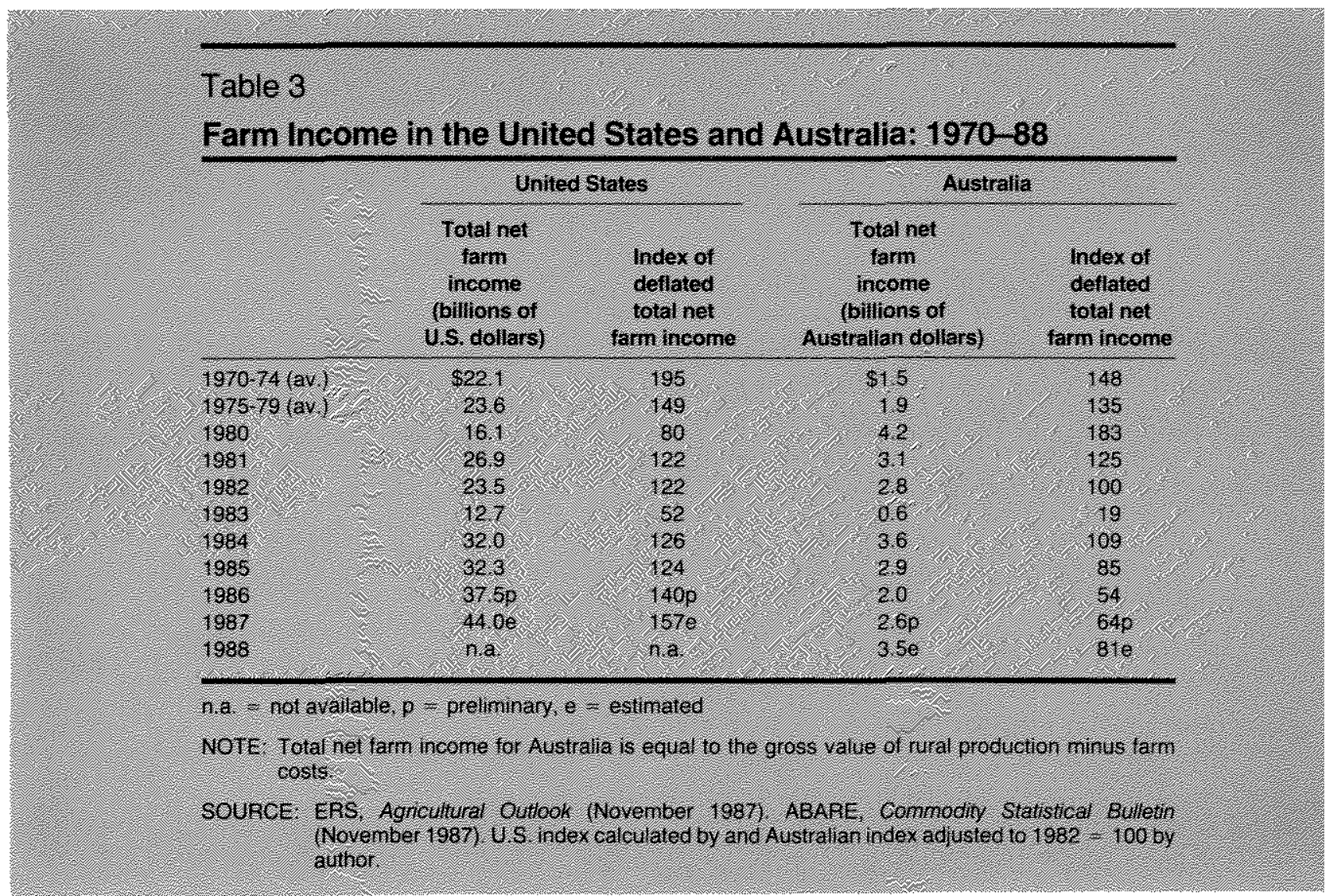




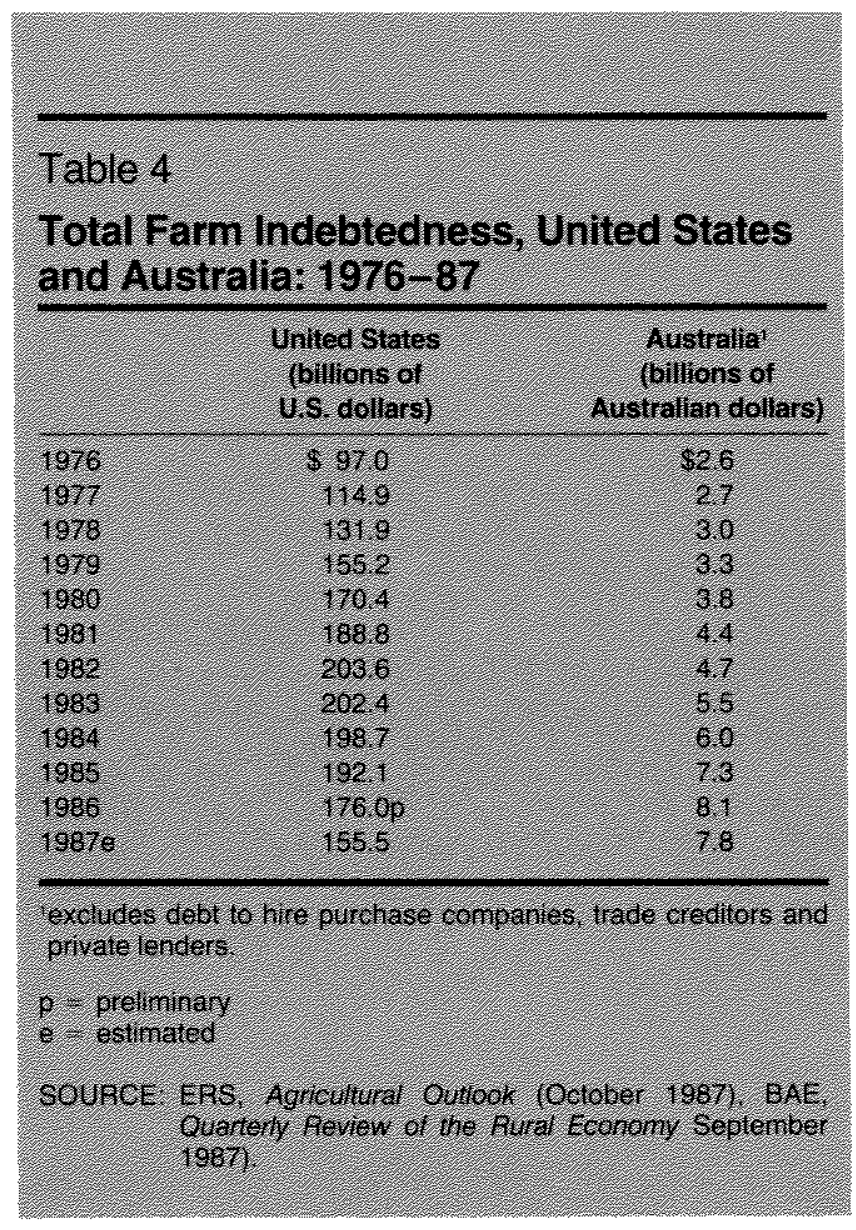

indebtedness in the United States increased less over this period than consumer prices.

Notwithstanding the increase in farm indebtedness, the ratio of fam debt to assets remains relatively low in both countries; however, Australian farmers have signifcantly lower measured debt-asset ratios than their American counterparts (table 5). Part of this difference may be due to differences in the liabilities included. It is notable that, apart from "other crop growers," Australian farmers did not experience sub. stantial increases in their debt ratio as did U.S. farmers over the period 1978 to 1986 . However, the increase in indebtedness and the rise to high levels in real interest rates caused an increase from 8 percent to 14 percent in interest payments' share in cash costs in Australian broadacre farming between 1978 and $1986 .{ }^{2}$

Changes in debt eatios reflect, in part, movements in land values, Falls in agricultural land values of 40 percent to 50 percent were common in the United

2Kingma (1987).

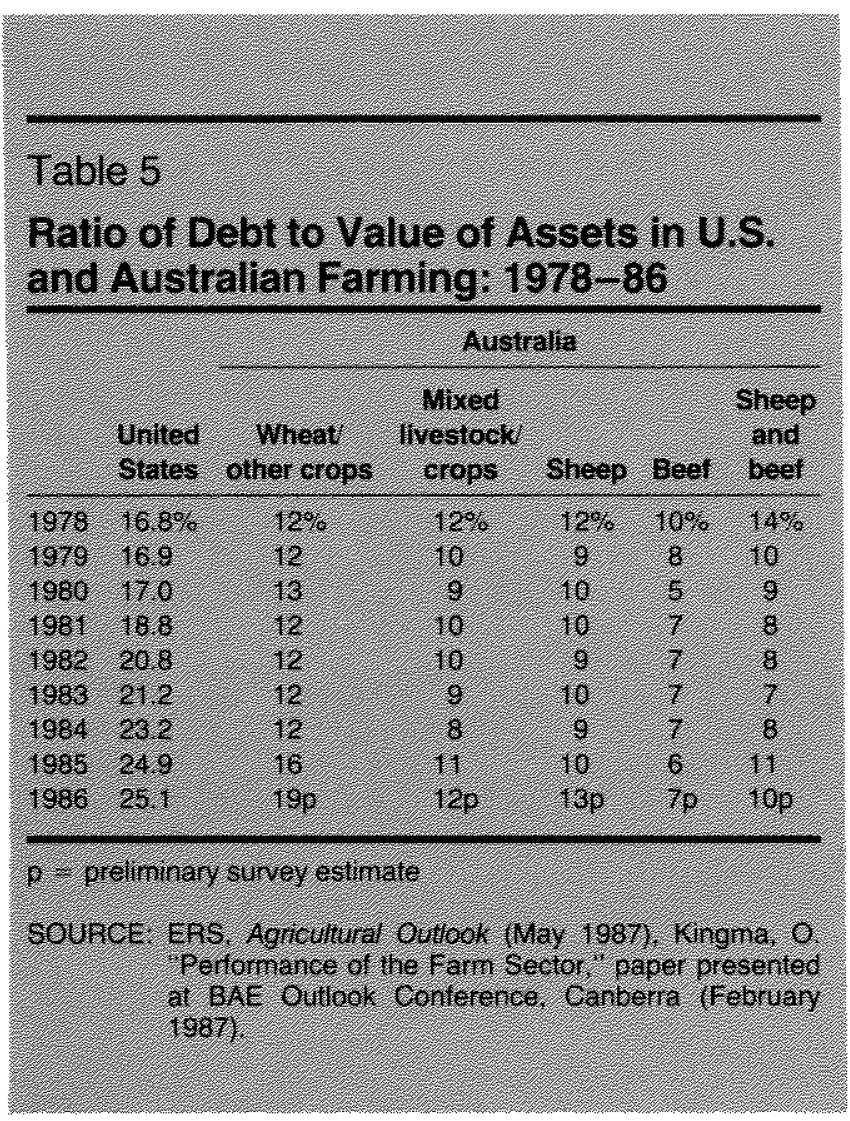

States in the five years to February 1986. In Australia, farm land price declines have been much smaller and confined mainly to cropping areas. Average land values in the important wheat-sheep belt are estimated by the ABARE to have risen until 1985, and to have fallen by 20 percent between 1985 and $1987^{3}$ After taking account of Australia's high inflation fate, the fall is 33 percent in real values.

There are important differences, arising largely from dissimilarities in climate and natural soil fertility, in farming practices in the United States and Australia, Approximately 70 percent of beef cattle are lot fed in the United States, while virtually all beef is produced on pastures in Australia. Similarly, dairy cows are not housed in Australia. Wheat grows in the winter in Australia and in the spring in the United States. Most Australian soils are deficient in phosphorus, and this is rectified by application of phosphatic fertilizers. However, United States farming makes much more intensive use of nitrogenous fertilizers. In Australia

TThe Bureau of Agricultural Economics became the Australian Bureau of Agricultural and Resource Economics in September, 1987.

4 McLeish and Spill (1987). 


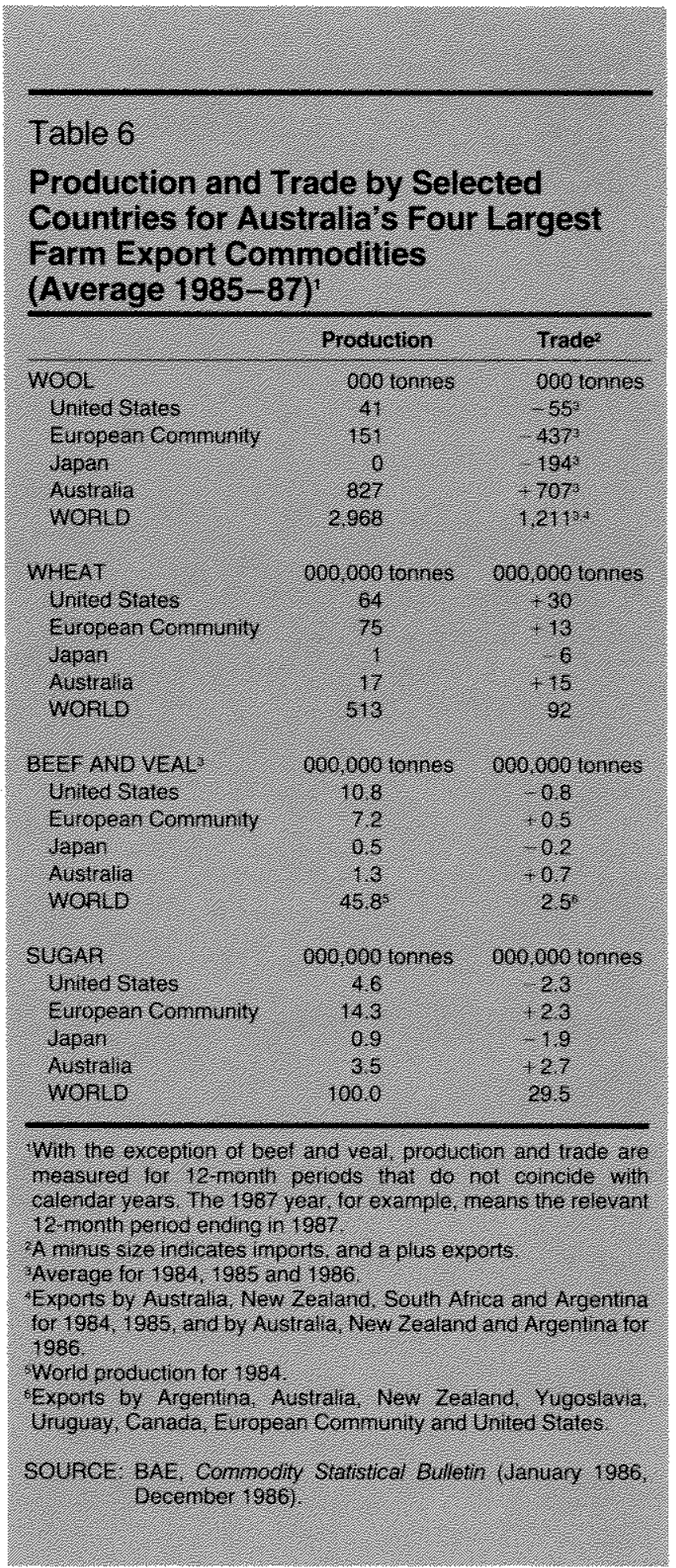

grain crops are normally grown in rotation with pastures containing legumes to provide nitrogen for use by pasture grasses and by subsequent crops.

A final important fact is the difference in the absolute size of agriculture in the United States and Austra lia. Both countries are significant players in international trade in Australia's four top farm export commodities (shown in table 6 in decreasing order of export earnings). For the two countries, the volume of beef and veal traded is similar, and this is true for sugar also. The United States exports twice as much wheat as Australia, while Australia is a much bigger player in world trade in wool.

On the production side, the United States produces much more of each commodity apart from wool: 30 percent greater for sugar; nearly four times as large for wheat and eight times as large for beef and veal. This means that, except for wool, there is much greater potential for changes in production in the United States - changes arising from developments in domestic farm policy, gains in productivity or other factors to influence world prices, and hence the benefits from trade to other exporting and importing countries. The European Community produces more wheat and sugar than the United States, but less beef and veal.

\section{U.S. FARM POLICY AND ITS INTERNATIONAL IMPACT}

Compared to Australia, the European Community and many other countries, agricultural policy in the United States is considerably more complex, and its eflects exceedingly difficult to assess. There are several reasons for this.

First the optional nature of fam programs for wheat, com and other grains means that policy analysts must assess separately the effect of programs on incentives and on producers' responses for program participants and non-participants. (Programs typically cause price changes for non-participants as well as for participants. The proportions of production that will be accounted for by each category of producers must also be estimated.

Second, substantial changes in U.S. farm programs occur frequently.

Third, U.S. fam policy relies heavily on a large number of policy instruments. Six of these instruments are listed in table 7 . The first column in table 7 summarizes the effect of each instrument on fam producer incentives in the United States. Each instrument is considered in isolation from the others; the effects shown are relative to a situation of no government intervention in agricultural markets.

The first instrument, mandatory unpaid land setasides, acts as a tax on farmers. The second instru- 


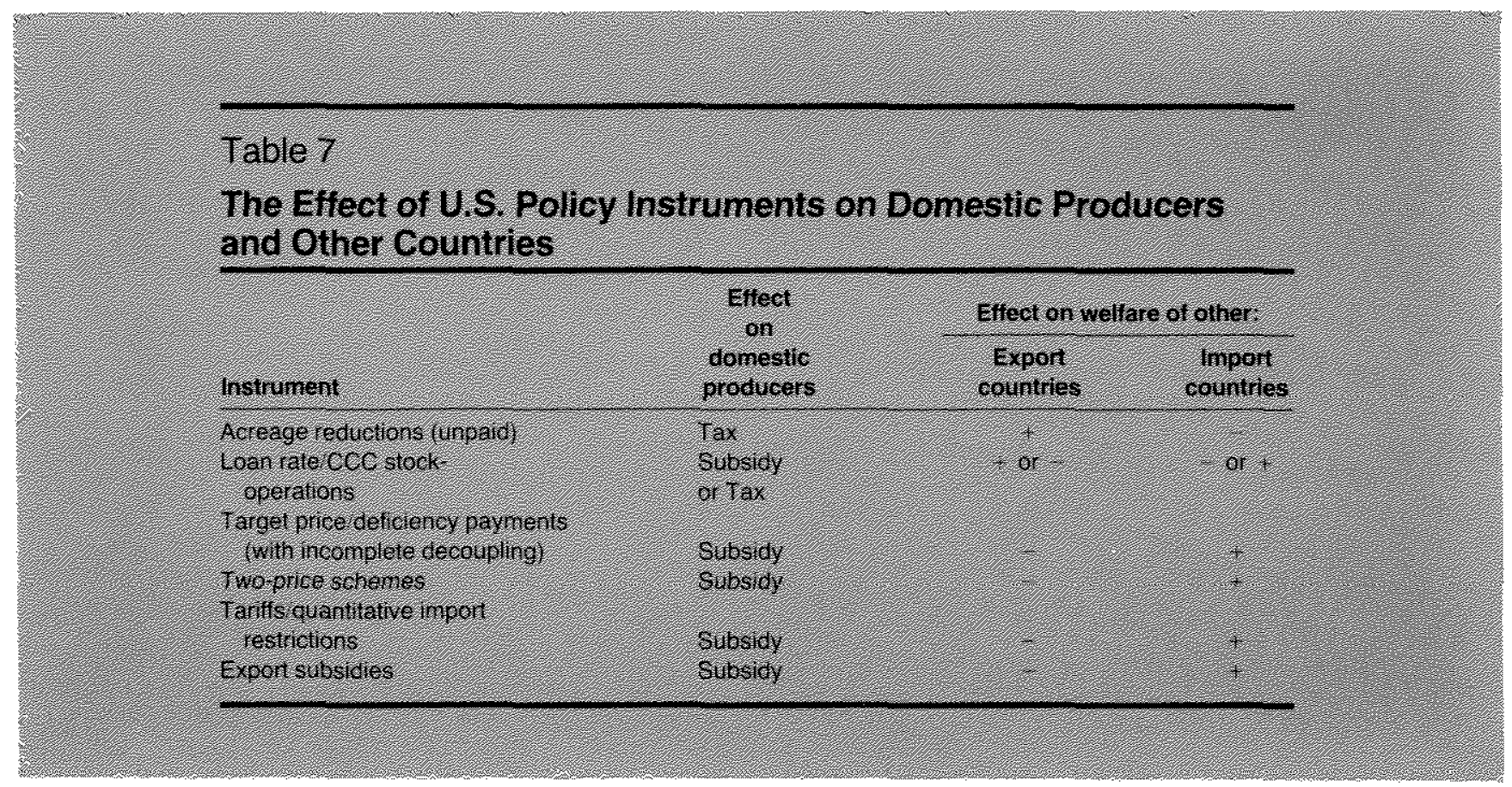

ment serves as a production subsidy when the loan rate is high relative to the world price, so that the Commodity Credit Corporation accumulates stocks. When the CCC releases stocks, the effect is equivalent to a tax on producers. The other instruments act as subsidies and, except for two-price schemes having a particular characteristic - farmess' return from their marginal production being equal to the world price encourage extra production.

The two final columns show the effect of each United States farm policy instrument on the net economic benefits to other countries. Most of the instruments shown reduce world prices, making other nations that export these commodities worse off, and importing countries better off. This is true of target prices achieved via deficiency payments, two price schemes the resulting reduction in U.S. consumption causes the world price to fall even if U.S. production is not increased), tariffs/quantitative import restrictions, and export subsidies.

The massive value of deficiency payments to United States farmers is illustrated by their capitalized values per acre. In 1985 these were: $\$ 450$ for wheat, $\$ 562$ for com, $\$ 1050$ for cotton and $\$ \$ 725$ for rice." If deficiency payments were made completely independent of cur-

${ }^{5}$ Council of Economic Advisers (1986). rent production as suggested by several U.S. congressmen and the Administration, deficiency payments could suppont farm incomes without inducing increase in production.

One important instrument of United States farm policy invariably works to raise world prices for farm commodities, and another policy sometimes does. Mandatory acreage teductions increase world price in two ways. First, they reduce production via a movement down the industry supply curve. Second, they increase costs per unit of output as farmers substitute fertilizers and other inputs in place of land. Of the instruments listed in table 7 , acreage reductions alone clearly benefit other exporting countries such as Australia.

When the loan rate for crops is set at a level that draws commodities from the commercial market into CCC stocks, the world price is raised. This was the situation in the period covered by the 1981 Farm Bill. When stocks are sold, however, other exporting countries are harmed, while importing countries benefit from the lower prices.

The effects of United States farm policies on output do not arise only through higher producer prices. These policies, especially the loan price and target price deficiency payment schemes, provide a much higher level of certainty about future prices that would exist in a free market. For example, the 1985 Farm Bill provided target prices for wheat to be maintained at their 1985 level of $\$ 4.38$ per bushel in 1986 and 1987 , 


\section{Table 8}

\section{Nominal Prolection Coefficients Ior Producer and Consumer Prices of Selected Commodities in Industrial Countries: 1980-82}

\begin{tabular}{|c|c|c|c|c|c|c|c|c|}
\hline & 40 & ale & $\begin{array}{l}\mathrm{Er} \\
\mathrm{eb}\end{array}$ & an & & & Oin & fates \\
\hline & $\begin{array}{l}\text { prod } \\
\text { lpe }\end{array}$ & Tipe & $\begin{array}{l}\text { Prod } \\
\text { APe }\end{array}$ & $\begin{array}{l}\text { Cons } \\
\text { NeE }\end{array}$ & $\begin{array}{l}\text { Prod } \\
\text { NPC }\end{array}$ & $\begin{array}{l}\text { Golss } \\
\text { lero }\end{array}$ & $\begin{array}{l}\text { Prod } \\
\text { Nice }\end{array}$ & Cons \\
\hline Wheat & 104 & 108 & 125 & 180 & 3.60 & 1.25 & 16 & 100 \\
\hline corarsegraths & 100 & 100 & 1,46 & 1.40 & 4.30 & .3 .30 & 1.00 & 100 \\
\hline II6e & 1.15 & 175 & 1.40 & 1.90 & 830 & 2.00 & 1.50 & 100 \\
\hline Bed ard larile & 40 & 100 & 190 & 190 & 400 & 400 & 100 & 100 \\
\hline Polkand poully & 200 & 1.00 & 1.25 & 1.25 & 1.50 & 150 & 100 & 1.00 \\
\hline 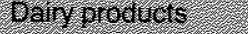 & 160 & 140 & 1.45 & 180 & 290 & 290 & 200 & 200 \\
\hline $81.9 a$ & 100 & 1.40 & 1.60 & 1.70 & 300 & 260 & 1.40 & 1.40 \\
\hline 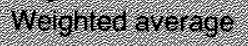 & 104 & 109 & 1,54 & 1.86 & 2.44 & 208 & 1,16 & 111 \\
\hline
\end{tabular}

declining to $\$ 4.29$ in $1988, \$ 4.16$ in 1989 and $\$ 4.00$ in 1990. Although the bill announced reductions in loan prices, teffectively minimum prices for producers' current production), it provided valuable reductions in uncertainty about prices through to 1990 . The greater certainty about prices provided by the target price and loan price undertakings of the Farm Bill means that risk-averse farmers find it attractive to produce at higher levels than they would do with the same expected prices but without the price guarantees.

While the role of price supports in producing the problems of global agriculture has rightly been emphasized, the contribution to surplus-generating investment provided by a high degree of certainty about process for several years ahead has been relatively neglected. While it is difficult empirically to separate these two effects, it is obvious that production would be reduced substantially if existing price support levels were provided in the form of subsidies on prices in free markets, with the price guarantees being removed.

Of course, the critical issue for Australian wheat or sugar producers is the overall effect that the entire package of policies making up the commodity program exert on other countries. While assessing this is complicated, some evidence on the effect of United States agricultural programs on world prices and trade can be presented.

\section{The Matter of Prices and Access}

The extent to which one nation's agricultural policies effect the economic fortunes of another coun- try depends mainly on the resulting price distortions in the former country and on the non-price restrictions placed on the latter country's trade.

A useful indicator of price distortions in agriculture is given by nominal protection coefficients for producer prices and consumer prices, These coefficients express domestic prices as the ratios of border prices, where border prices can be considered as export prices for export situations and import prices for import situations. Information on nominal protection coefficients for producer and consumer prices for the United States, Australia, the European Economic Community and Japan for the years 1980-1982 is shown in table 8 .

Rates of producer protection were at least as high in the United States as in Australia for each of the seven commodities. The figures in the bottom row indicate that United States price supports encouraged aggregate agricultural production much more than Austram lian pricing policies did. Overall, the price of food to consumers was also raised more by market interventions in the United States than in Australia, although buyers of wheat and rice fared better in the United States. Policies that raise domestic consumer prices also ham other export countries by increasing the output that must be disposed of on other world mar kets.

For perspective it should be noted that producer and consumer prices were higher relative to world prices in the European Economic Community than in the United States, and they were much higher still in Japan. 
Rates of producer subsidy would generally have been higher in more recent years than in the years 1980-1982. This is due manly to the lower level of world prices - against which subsidy rates are measured. Anderson and Tyers 1987 projected average producer to border price ratios of 1.5 for United States agriculture in 1988 and 2.0 for all industrial market economies.

Australia's top rural export is not included in table 8. Wool growing is very lightly assisted through government intervention in Australia. The United States tariff of 10 cents a pound (clean) on wool appears to be a relatively minor impediment to Australian exports of wool in this market. In addition to the benefits conferred by the tariff, United States wool growers received payments from taxpayers amounting to about 20 percent of their cash receipts in $1985^{\circ}$

Australia's agricultural trading opportunities are not restricted only by policy interventions that raise prices to overseas producers and consumers. It also faces quantitative restrictions on access of some commodities to major markets. Restrictions on exports of beef and sugar to the United States are important cases.

\section{The Impact of U.S. Farm Policies on International Trade}

The Bureau of Agricultural Economics has estimated that the Common Agricultural Policy of the European Economic Community caused income losses to Australian farmers of almost $\$ A 1$ billion a year in the five years to $1985 .^{7}$ That was around 14 percent of the gross value of exports of the six commodities included in the study - wheat, coarse grains, sugar, beef, sheep, meat and dairy products in 1985. No comparable estimate has been made of the effects of United States farm policies on the income of Australian farmers. The greater complexity of farm policy in the United States than in the European Economic Community, and the greater frequency of major policy changes, are strong deterrents 10 attempts to duplicate the European Community study for the United States. However, two major projects are in progress in the Australian Bureau of Agricultural and Resource Economics of the international consequences of United States farm policies. One project focuses on grains and the other is more general in scope.

\footnotetext{
${ }^{6}$ Economic Research Service (1986),

'Bureau of Agricultural Economics (1985).
}

The World Bank has published estimates of the effects on world prices and world trade volume of removing policies in major countries and blocs that cause prices of agricultural commodities to differ from world prices. These estimates provide a general indication of the way a small trading country such as Australia would be affected by liberalization of commodity markets in large countries. Some of these estimates are shown in table 9. Note that liberalization in a country or bloc means that policy-caused price distortions are removed simultaneously for all seven commodities, so that the results reflect interactions between the commodities as liberalization changes relative prices to producers and/or consumers.

Except for wheat and coarse grains, liberalization in the United States is estimated to have a much smaller effect on world prices, and hence on other exporters such as Australia, than liberalization in the European Economic Community. A movement to free commodity markets in the United States is found to reduce the world price for coarse grains, to the detriment of other exporters. This appears to be due to the removal of acreage restrictions and to substitution of coarse grains for wheat upon liberalization.

World trade volume for coarse grains, pork and poultry, and dairy products are found to increase more with removal of protection in the United States than in the European Community. Prices and trade volume for beef and lamb are increased much more by market oriented policies in Japan than by liberalization in the United States or the European Community.

\section{THREE APPROACHES TO MORE OPEN AGRICULTURAL TRADE MARKETS}

Solutions to the problems of distorted and restricted agricultural trade can be sought through uni* lateral, bilateral and multilateral actions.

The balance between domestic benefits and costs can be expected to determine action under each of these approaches. The most plausible explanations of govermment intervention in agriculture emphasize economic characteristics (such as price elasticity of demand and number of producers/ which detemine an industry's effectiveness in seeking assistance, and the

${ }^{8}$ The World Bank pointed out that the figures in table 9 almost certainy underestimaled the benefits to developed countries from rade liberalization. 


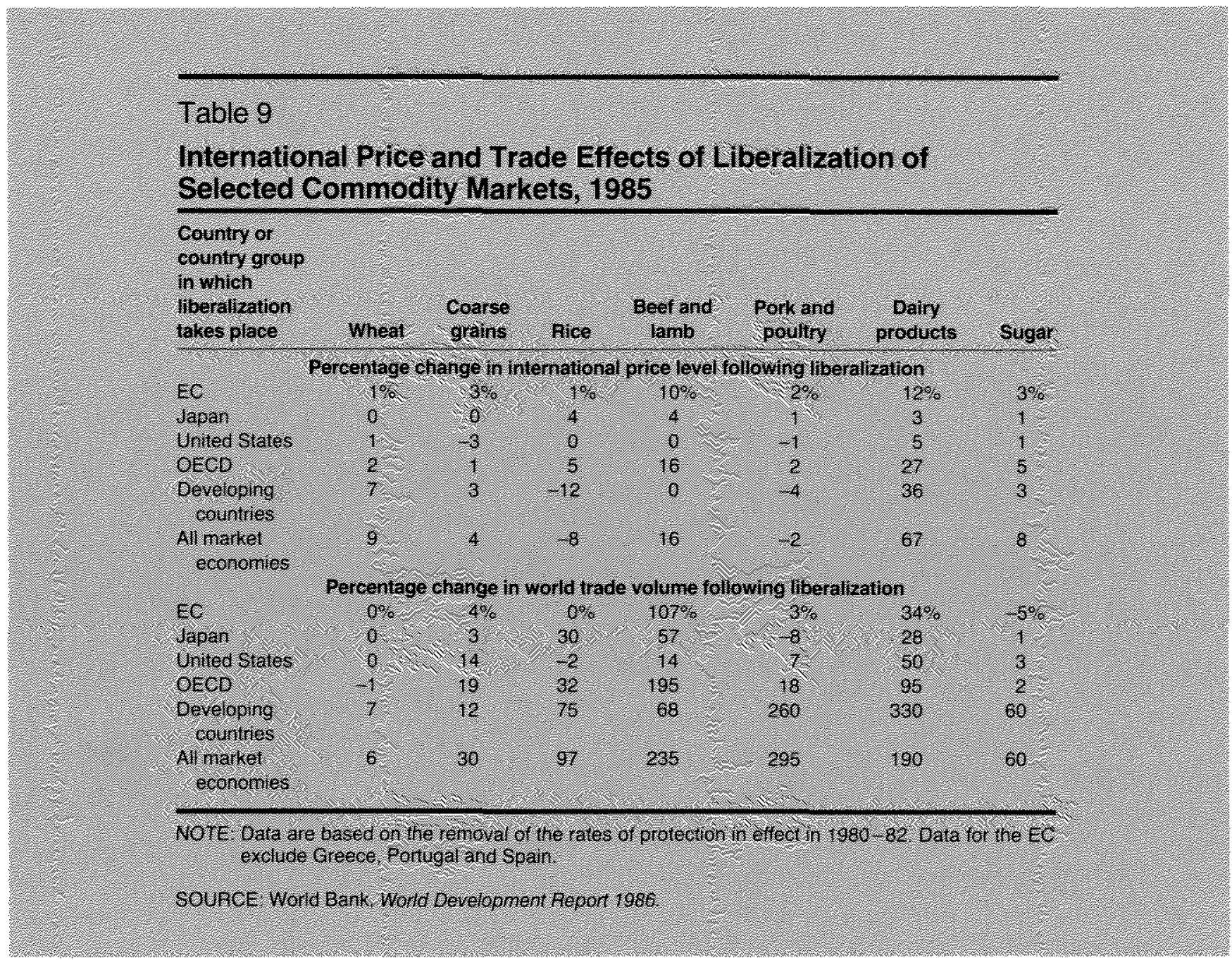

costs of providing assistance. ${ }^{9}$ A consequence of this view, in contrast to the alternative "public interest" explanation for trade in interventions, is that governments are unlikely to change their programs quickly in response to new studies revealing that interventions are costly to the overall community. Nevertheless, research and education can educate the electorate about the costs and benefits of agricultural programs. ${ }^{11}$

\section{Unilateral Changes in U.S. Farm Policy}

Many suggestions have been made for reforming United States fam policy. An interesting comparison of the effects of the Food Security Act 1985 and of six

अFor example, Gardner (1987); von Witzke (1986); Sieper (1982),

to One development is a large study of the economic effects of agricultural policies in several countries that is being coordinated by the Australian consultants Andy Stoeckel and Sandy Cuthbertson and funded by the Australian and United States governments and Australian farmers. other farm policy proposals, as prepared by Resources for the Future, is reproduced in table 10; it ranks the various policies in decreasing order of desinability to each of three groups: farmers, agribusiness and

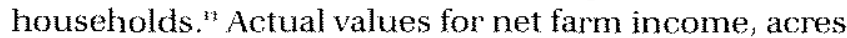
planted the criterion for ranking the policies from the perspective of agribusiness and food and tax costs per household are also shown for most policies.

Not surprisingly, the policies rated as best for pro" ducers (mandatory supply controls with export subsidies, and two price schemes rank near the bottom for agribusiness and for households. On this approach, the interests of agribusiness are more closely alligned to those of consumers (laxpayers) than they are with producers. This increases the prospects for reform of United States farm policies in ways favorable to households. Market-oriented policies involving complete of

\footnotetext{
${ }^{17}$ Resources for the Future (1987).
} 


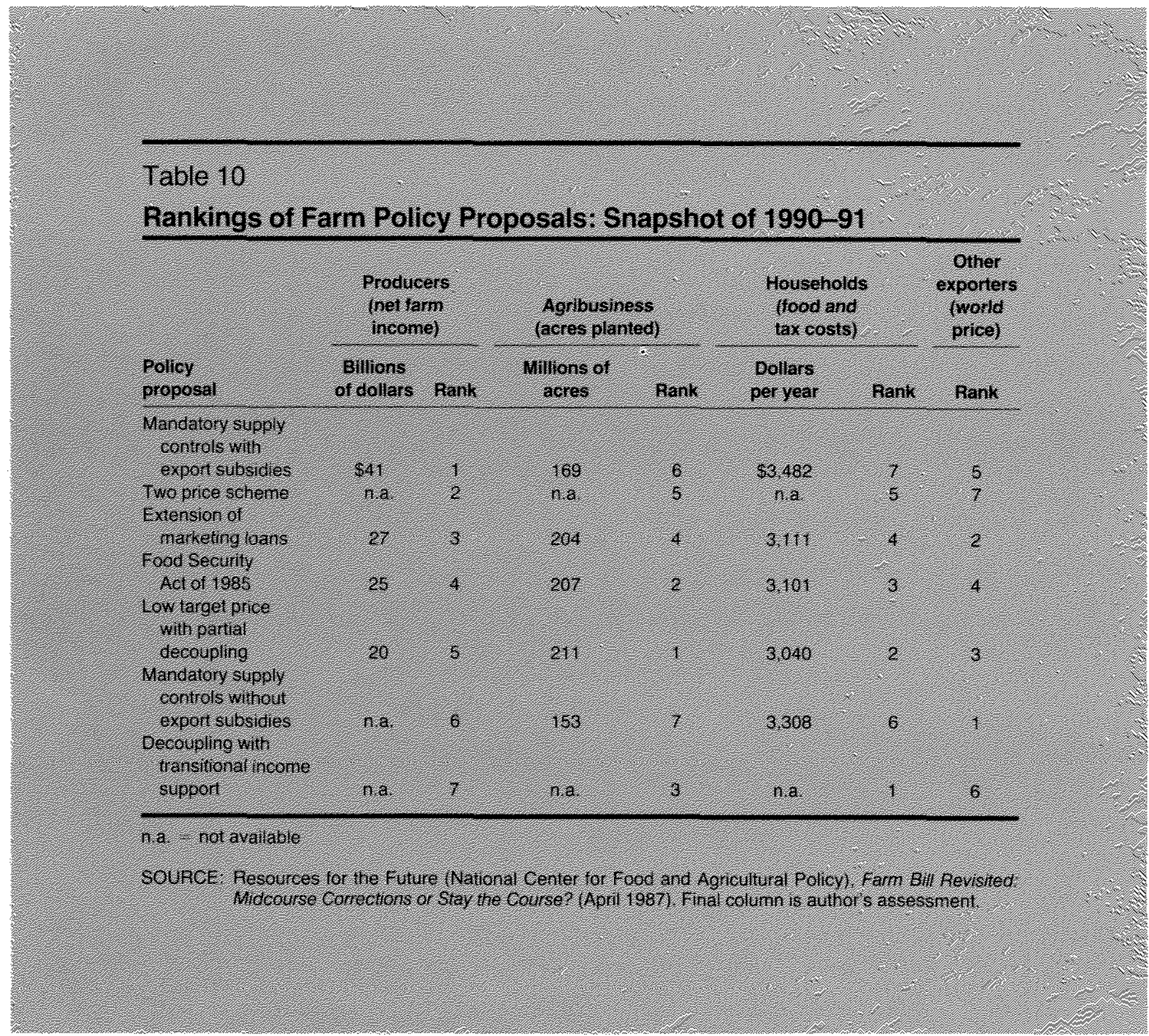

partial decoupling of producer assistance from current production rank highest from the view of households.

I have added a ranking of the policies from the perspective of other exporting countries, such as Australia. Unilateral use of mandatory supply controls, with idling of 127 million acres (more than 40 percent of the total cropland basel in 1991, is the policy that Australian farmers would endorse most enthusiastically. However, mandatory supply controls rank very poorly for all U.S. interest groups. Of some comfort to other exporting nations, perhaps, is that the worst U.S. policies from their perspective (two price schemes, decoupling with transitional income support, and supply controls with export subsidies) would be un- popular also with at least one of the domestic U.S. groups..$^{22}$

\section{Bitateral Liberalization}

Agreements reached between two countries to reduce trade barriers may be consistent with the General Agreement on Tariffs and Trade (GATT) objective of increasing world trade. This depends on whether

12|t the United States were more concerned about the foreign relations fallout from its farm policies on countries importing agricultural commodties, the relevan ranking would be the severse of that in the final column of table 10 . That would increase the attractiveness of two price schemes, decoupling with temporary income supports and supply controls with export subsidies. 
the extra trade that results between the fwo countries is mainly a net adalion to world trade or is obtained largely by reducing other countries' trade. Although free trade areas between two or more countries are permitted under Article 24 of GATT, bilateral trade liberalization appears inconsistent with the GATT most favored nation principle of extending to all GATT members reductions in trade impediments negotiated with a particular member country.

\section{The Multilateral Approach}

GATT is the only forum for the detailed negotiations required in an international approach to reducing impediments to freer trade. The fact that so fittle was achieved toward freer world agricultural trade in the previous seven GATT rounds is not a good omen for the round that commmenced in Punta del Este, Uruguay, in September 1986. Increased pressure from other international groups, notably the Organization for Economic Cooperation and Development (OECD) and the Economic Summit Countries, will be important for progress towards a more liberal agricultural trade regime in the current GATT round.

The United States tabled its Uruguay round proposal for agriculture with GATT in Geneva in July 1987. Australia's proposal is contained in the joint submis sion from the Cairns Group members, tabled in October 1987. While there are significant differences between the two proposals, these are much less important than the remarkable degree of common ground.

The United States and Australian (Caims Group) proposals both called for:

- the phasing out by the year 2000 of all policy measures that directly or indirectly subsidize agticultural production and all measures that limit market access:

- the use where governments provide income support for farmers of measures that make payments independent of current levels of production and marketing;

- the reform of GATT rules and disciplines consistently with the above.

Agreement on these steps in the Uruguay round, and their implementation, would ensure a new $w_{3}$ liberal era in world agricultural trade.

In deciding whether to participate actively in GATT efforts to reduce agricultural assistance multilaterally, each nation will likely compare the economic effects of multilateral liberalization on domestic groups with the economic effects of reducing assistance independently of other countries. The differences arise from the larger increase in world prices when protection is removed from a bigger share of world production under multilateral liberalization.

Anderson and Tyers (1987) have estimated the effects of gradually removing agricultural assistance by individual countries or groups of countries, and by many countries simultaneously, over the period 1988 to 1995 that throws light on this. Some of their results are shown in table 11. U.S. producers would lose approximately $\$ 22$ billion in 1995 if the U.S. removes agricultural protection unilaterally, This large producer loss becomes a gain of $\$ 3$ billion if liberalization occurs in all advanced market economies, In the European Economic Community, unilateral liberalization would cost producers an estimated $\$ 89$ billion; this would be reduced to only $\$ 74$ billon if liberalization occurred in all industrial market economies.

If, as seems likely, govermment decisions on reducing agricultural assistance depend mainly on the way producers are affected, the multilateral approach appears much more attractive for the United States than going it alone. It is much less clear that either approach to liberalization would appeal to the European Economic Community. This poses a substantial problem for negotiations in the GATT round.

Producers in Japan lose heavily from multilateral liberalization, as they do from unilateral removal of protection. Japan, also, can be expected to oppose both routes to freer markets if producer interests predominate.

In Australia and New Zealand, by contrast, farmers would experience significant net gains in income under the "let's all do it together" route. The losses (not shown in the table) from removal of their own (generally modest) assistance would be easily outweighed by the increases in world prices resulting from removal of much larger price distortions by the big players. Producers in Australia and New Zealand can be expected to be more enthusiastic about multilateral liberalization than farmers in the United States.

Taking economic gains to consumers (taxpayers) as the difference between net economic welfare and producer gains in table 11, the results suggest that other groups in the European Economic Community and, more so, in the United States would prefer unilateral to multilateral reform. This, also, may not augur well for progress in the GATT round. 




\section{CONCLUDING COMMENTS}

Australian farmers and Australia as a nation are harmed by United States farm policies, though less than they are by the agricultural policies of the European Economic Community. These effects are experienced through power world commodity prices and trade volumes and increased instability of prices. Measures of the international effects of agricultural protectionism in major countries and blocs often understate the true effects. One reason for this is that protectionist measures often reduce domestic price uncertanty, as well as raising producer prices. The effects of reduced uncertainty on investment and output can be substantial, but frequently they are not captured in measures of the impacts of policies.

Implementation in the United States of Administration proposals to reduce the assistance provided to farmers via subsidies and price supports, and reorienfation of assistance to supporting incomes independently of production, would be welcomed in Australia. Similarly, the thrust of the United States proposal to GAT"T for multitateral phasing out of agricultural subsidies and barriers to imports between 1990 and 2000 has been called "bold and imaginative" by Australia's prime minister.
However, both in multilateral negotiations and in domestic policymaking, the powerful forces that have caused existing policies to be introduced and maintained will not easily be overcome. United States famers will oppose more market-oriented policies if they lower their incomes. They will prefer multilateral reductions in agricultural protection, which will push world prices up more, to unilateral reductions confined to the United States. Moreover, they stand to gain relatively much less from multilateral reductions than do Australian famers. With the relatively small gatn to U.S. farmers and the large losses for European Community and Japanese farmers from phasing out agricultural protection, it is easy to be somewhat pessimistic about the outcome of agricultural negotiations in the current GAT T round.

If production-oriented support programs that have produced the global agricultural crises are to be replaced by market-oriented policies supplemented by production-independent income supports, consumers and taxpayers must be convinced that it is worthwhile to adopt more cost-effective approaches to bolstering farmers' incomes. 


\section{REFERENCES}

Anderson, K., and R. Tyers. Global Effects of Liberalizing Trade in Agriculture (London: Trade Policy Research Centre, 1987).

Bureau of Agricultural Cconomics. "Agricultural Policies in the Eurupean Community," Policy Monograph No. 2 (Canberra: Australian Government Publishing Service, 1985).

Carmichael, W.B. "National Interest and International Trade Negotiations," T/e Wurld Ecomunly (Decernber 1986), pp. 341-57.

Council of Economic Advisers, Economic Report of the President (U.S. Government Printing Office, 1986, 1987).

Dam. K.W. The GATT I aW and Fronnmir Organization (I Iniversity of Chicago Press, 1970).

Economic Research Service. Government Intervention in Agriculture: Measurement, Evaluation and Implications for Trade Negotiations, U.S. Department of Agriculture (GPO, 1987).

Gardner, B.L. "Causes of U.S. Farm Commodity Programs," Journal of Political Economy (April 1987), pp. 290-310.

Hathaway, D.E. "Trade Negotiations: They Won't Solve Agriculture's Problems," Choices (Fourth Quarter 1986), pp. 14-17.

Hawke, R. Speech to the Contracting Parties of the GATT, Geneva, October 22, 1987.

Kingma, O. "Performance of the Farm Sector," paper presented at Annual BAE Outlook Conference, Canberra (February 1987).
McLeish, R. and M. Spill. "Livestock - Feed Grain Linkages in The Pacific Basin: The Impact of a Fall in Grain Prices," paper presented at Livestock and Feedgrains Study Program Pacific Economic Cooperation Conference, Napier, New Zealand, October 1987.

Pearlberg, R. "International Agricultural Policy Coordination: An Impediment to Liberal Reforms," paper presented at Benjamin E. Lippincott Symposium, Policy Coordination in World Agriculture (Minneapolis: University of Minnesota, April 1987)

Rausser, G.C. and B.D. Wright, "Alternative Strategies for Trade Policy Reform," paper presented at Benjamin E. Lippincott Symposium Policy Coordination in World Agriculture (Minneapolis: University of Minnesota, April 1987).

Resources for the Future, National Center for Food and Agricultural Policy. The 1985 Farm Bill Revisited: Midcourse Corrections or Stay the Course? (Washington, D.C., 1987).

Sanderson, F. "Putting Agrlculture In the GATT: Comment" (Resources for the Future, Washington, D.C., May 1986).

Sieper, E. Rationalizing Rustic Regulation (Sydney, Australia: Centre of Independent Studies, 1982).

World Bank. World Development Report 1986 (Oxford University Press, 1986).

von Witzke, H. "Endogenous Supranational Policy Decisions: The Common Agricultural Policy of the European Community," Public Choice (1986), pp. 157-74. 